nellew

\title{
Mineralocorticoid receptors in the heart: lessons from cell-selective transgenic animals
}

\author{
Morag J Young ${ }^{1,2}$ and Amanda J Rickard ${ }^{1,2}$ \\ ${ }^{1}$ Cardiovascular Endocrinology, MIMR-PHI Institute, 27-31 Wright St, Clayton 3168, Australia \\ ${ }^{2}$ Department of Physiology, Monash University, Clayton 3168, Australia
}

Correspondence should be addressed to $M$ Young

Email morag.young@princehenrys. org

\begin{abstract}
The clinical impact of cardiovascular disease cannot be underestimated. Equally, the importance of cost-effective management of cardiac failure is a pressing issue in the face of an ageing population and the increasing incidence of metabolic disorders worldwide. Targeting the mineralocorticoid receptor (MR) offers one approach for the treatment of heart failure with current strategies for novel MR therapeutics focusing on harnessing their cardio-protective benefits, but limiting the side effects of existing agents. It is now well accepted that activation of the MR in the cardiovascular system promotes tissue inflammation and fibrosis and has negative consequences for cardiac function and patient outcomes following cardiac events. Indeed, blockade of the MR using one of the two available antagonists (spironolactone and eplerenone) provides significant cardio-protective effects in the clinical and experimental setting. Although the pathways downstream of MR that translate receptor activation into tissue inflammation, fibrosis and dysfunction are still being elucidated, a series of recent studies using cell-selective MR (NR3C2)-null or MR-overexpressing mice have offered many new insights into the role of MR in cardiovascular disease and the control of blood pressure. Dissecting the cell-specific roles of MR signalling in the heart and vasculature to identify those pathways that are critical for MR-dependent responses is an important step towards achieving cardiac-selective therapeutics. The goal of this review is to discuss recent advances in this area that have emerged from the study of tissue-selective MR-null mice, and other targeted transgenic models and their relevance to clinical disease.
\end{abstract}

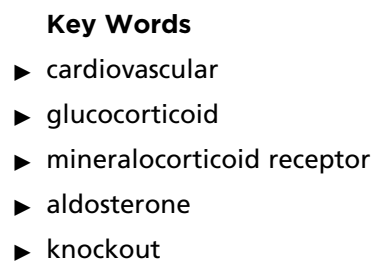

Journal of Endocrinology (2015) 224, R1-R13

\section{Introduction}

The primary physiological role of aldosterone is to stimulate ion transport in epithelial cells, in particular in the distal nephron and distal colon (Grundy et al. 1952). In epithelial cells, aldosterone stimulates sodium reabsorption and, by doing so, has direct effects on potassium and magnesium secretion and chloride reabsorption (Crabbe 1963, Wright \& Giebisch 1978).
Aldosterone also has profound effects on the cardiovascular system, altering gene expression and influencing vascular tone, cardiac contractility and tissue composition. Moreover, it is becoming increasingly evident that the mineralocorticoid receptor (MR) exerts both cell- and ligand-specific actions in the cardiovascular system. The recent publication of a series of transgenic mouse models

Published by Bioscientifica Ltd. 
targeting the MR in the cardiovascular system have highlighted novel and distinct roles for MR signalling in vascular smooth muscle cells (VSMCs), endothelial cells, cardiomyocytes and monocytes/macrophages in cardiac physiology and pathophysiology. These models represent important tools for understanding the specificity of MR action and have revealed many new mechanisms of action that were not possible in earlier pharmacological studies. The present review will discuss the importance of novel, cell-specific roles of MR signalling in the cardiovascular system.

\section{MR signalling in cardiac health and disease}

Hans Selye first noted the pathological role of adrenal hormones in 1946; 50 years later, the significance of these findings was truly appreciated when inappropriate aldosterone-for-salt status in rodents was shown to produce hypertension, cardiac hypertrophy and fibrosis (Selye 1946, Brilla \& Weber 1992). Large-scale clinical trials have subsequently validated the importance of MR signalling in cardiac pathology in patients with severe allcause heart failures (RALES), heart failure post myocardial infarction (EPHESUS) or mild heart failure (EMPHASIS-HF; Pitt et al. 1999, 2001, Zannad et al. 2011). Addition of a low dose of spironolactone or the highly selective MR antagonist, eplerenone, to standard 'best practice' treatment with renin-angiotensin system inhibitors and $\beta$-blockers, reduces cardiovascular mortality and morbidity in patients with heart failure. Unfortunately, the clinical use of MR antagonists is limited by the side effect profile, which results from the blockade of renal tubule MR and the consequential elevation of serum potassium levels. Novel therapeutic options, which reduce MR activity in the heart while sparing renal function, would be beneficial. An increasing number of studies aim to elucidate the hormonal mechanisms and signalling pathways involved in MR-mediated cardiac pathology to facilitate the design of novel therapeutic approaches.

\section{Regulation of the MR epithelial vs non-epithelial mechanisms}

The MR is a member of the steroid hormone receptor family of ligand-activated transcription factors that share structural homology with glucocorticoid (GR), progesterone, androgen and, to a lesser extent, oestrogen receptors respectively. The MR is, however, unique in that it can bind multiple classes of ligand including the mineralocorticoids, aldosterone and deoxycorticosterone
(DOC), and the GRs, cortisol or corticosterone. True mineralocorticoid responsiveness is achieved in the epithelial cells of the distal nephron, and blood vessel wall, via the action of $11 \beta$ hydroxysteroid dehydrogenase type 2 (HSD2). The absence of HSD2 in non-epithelial cells - heart, brain, adipose and inflammatory cells results in cortisol (or corticosterone in rodents) being the predominant ligand for MR. Thus, in these tissues, MR serves to increase the dynamic range of cortisol/ corticosterone signalling, given that they can signal via the high-abundance, low-affinity GR and the lowabundance, high-affinity MR.

MR signalling can also be mediated by a number of other important cell signalling mechanisms including transrepression and second messenger pathways. Transrepression involves a protein-protein interaction with sequestration of other transcription factors of which the best characterised example is GR and the transcription factors AP1 and NFאB, which mediate an antiinflammatory effect. Conversely, both transactivation and mutual transrepression of the MR by NFкB have been reported (Pearce \& Yamamoto 1993, Kolla \& Litwack 2000, Fiebeler et al. 2001, Chantong et al. 2012). To date, signalling pathways characterised as mediating rapid MR/aldosterone responses include the protein kinase C family and the MAPK family (Gekle et al. 2001, McEneaney et al. 2008, McEneaney et al. 2010). Rapid MR signalling can also regulate intracellular levels of calcium, cAMP and nitric oxide (NO; Wehling 1994, Christ et al. 2005, Hashikabe et al. 2006). These responses can be mediated via the classical MR and may also occur via the MR being putatively membrane-bound (Grossmann et al. 2005). The MR can be localised to the membrane, for example via interactions with epidermal growth factor receptor (EGFR) and studies demonstrate that the genomic MR is required for rapid corticosterone signalling in the brain (Karst et al. 2005, Grossmann et al. 2010). By contrast, rapid aldosterone signalling is retained in MR (NR3C2)-null cardiac cells and recent studies have suggested that a $G$ proteincoupled receptor, GPR30, may serve as a novel aldosterone receptor, as it does for oestrogen (Haseroth et al. 1999, Gros et al. 2011).

In addition to regulation of pre-receptor ligand availability, canonical MR signalling is also regulated by the specific combination of coregulatory proteins that associate with the ligand-bound receptor as well as the DNA sequence in the promoter of the target gene to which the complex is bound. This has been recently reviewed elsewhere (Yang \& Fuller 2012).

Published by Bioscientifica Ltd. 


\section{MR signalling in the vessel wall: VSMCs and endothelial cells}

VSMCs, the contractile units of vascular walls, exhibit remarkable plasticity (Owens 1995). This plasticity is exemplified by their response to vascular injury, whereby VSMCs dramatically increase cell proliferation, migration and synthetic capacity to facilitate vascular repair. However, the high degree of plasticity can also contribute to vascular disease states including atherosclerosis and hypertension (Owens et al. 2004).

\section{VSMC MR and vascular tone}

In the kidney, the MR response to aldosterone is a key regulator of blood pressure via stimulation of sodium and water retention in the epithelial cells of the distal nephron. However, the extra-renal actions of MR can also have profound effects on the development of hypertension and the associated cardiovascular mortality. An important component of blood pressure control is arterial stiffness, which is also an important risk factor for cardiovascular disease. A number of recent studies have suggested that VSMC MR play a direct mechanistic role in vascular compliance and thus extra-renal blood pressure control. Mice in which VSMC MR genes were selectively deleted using an inducible Cre-recombinase approach identified an important role for extra-renal MR signalling in agedependent blood pressure elevation (McCurley et al. 2012). Loss of VSMC MR resulted in a lower blood pressure as the mice aged, despite no change in their renal sodium handling or vascular structure. A reduction in vascular tone and contractile function of the vessel wall was identified as a key mediator of these effects, which may be dependent upon MR regulation of L-type calcium channel activity. Hypertensive responses to angiotensin II and other vasoactive substances, vascular oxidative stress and vascular contractility were also shown by the authors to be dependent upon VSMC MR. These data are also consistent with a close relationship between the MR and angiotensin II signalling in the control of vascular function.

\section{VSMC MR and vascular remodelling}

VSMCs play a fundamental role in vascular remodelling and vascular reactivity. MR activity in VSMCs promotes vascular remodelling in response to endothelial cell injury, independently of blood pressure responses (Jaffe et al. 2010). Mechanisms of MR-dependent vascular remodelling include galectin 3 signalling, which serves as an aldosterone-dependent regulator of vascular fibrosis and inflammation, and protein kinase $\mathrm{B}$, which is required for aldosterone-induced vascular apoptosis and structural injury (Wei et al. 2009).

MR-dependent vascular remodelling has also been demonstrated in the venous system. The MR is upregulated in human venografts and MR antagonists can preserve graft patency (Ehsan et al. 2013). Vascular remodelling is a key feature of atherosclerosis and is dependent upon both turbulent flow in the aorta and activation of the MR (McGraw et al. 2013). Aldosterone significantly increases the development of early atherosclerotic changes in the aorta as well as increasing the degree of inflammation of plaques in Apoe-null mice. The authors identified placental growth factor (PIGF), a secreted growth factor and monocyte chemoattractant that binds the vascular endothelial growth factor receptor 1 (VEGFR1) on monocytes, as a critical mechanism downstream of the MR in the generation of plaque instability in the vessel wall. These detrimental processes are independent of haemodynamic changes, although the presence of endothelial cell injury has synergistic actions with VSMC MR signalling outcomes.

VSMC MR-null mice have a reduced vascular fibrotic response to both aldosterone treatment and a wireinduced carotid injury that is also associated with the loss of VEGFR1 signalling (Pruthi et al. 2014). A similar mouse model of MR-null VSMCs, this time using a constitutive Cre to drive recombinase activity, investigated MR signalling in vessel wall remodelling and compliance (Galmiche et al. 2014). In contrast to the previous model, these mice show lower blood pressure in the unchallenged state, which is consistent with the previously described reduced vasomotor tone. The elastic properties of the arterial wall of the aorta or carotids were not different between WT and VSMC MR-null mice at baseline but when challenged with aldosterone and salt, an increase in wall stiffness was detected in WT mice only. Although there was a similar induction of fibronectin and collagen between genotypes, the significant reduction in expression of a matrix attachment protein integrin $\alpha 5$ in VSMC MR-null mice may result in reduced cell matrix attachments and account for reduced vascular stiffness (Galmiche et al. 2014; Table 1).

\section{Endothelial cells and MR}

Endothelial cells are a highly heterogeneous cell population that differ in terms of morphology and function throughout the vascular tree (Fishman 1982). They are

Published by Bioscientifica Ltd 
Table 1 Comparison of phenotypes in tissue-selective MR-null mice

\begin{tabular}{|c|c|c|c|c|}
\hline & VSMC & Endothelial cell & Cardiomyocyte & Macrophage \\
\hline Blood pressure & $\begin{array}{l}\text { BP regulation in } \\
\text { ageing }\end{array}$ & $\begin{array}{l}\text { No direct role in } \mathrm{DOC} / \mathrm{salt} \\
\mathrm{BP} \text { regulation }\end{array}$ & $\begin{array}{l}\text { No direct role in DOC/salt or } \\
\text { L-NAME/salt BP } \\
\text { regulation }\end{array}$ & $\begin{array}{l}\text { DOC/salt BP regulation } \\
\text { Delayed L-NAME/salt } \\
\text { increase in BP }\end{array}$ \\
\hline Tissue remodelling & $\begin{array}{l}\text { Aldo/salt induction } \\
\text { of VSMC } \alpha 5 \text {-sub- } \\
\text { unit integrin }\end{array}$ & DOC/salt cardiac fibrosis & DOC/salt cardiac fibrosis & $\begin{array}{l}\text { DOC/salt and L-NAME/salt } \\
\text { cardiac fibrosis }\end{array}$ \\
\hline $\begin{array}{l}\text { Cardiac macrophage } \\
\text { recruitment }\end{array}$ & & $\begin{array}{l}\text { DOC/salt macrophage } \\
\text { recruitment }\end{array}$ & $\begin{array}{l}\text { DOC/salt macrophage } \\
\text { recruitment }\end{array}$ & $\begin{array}{l}\text { No direct role in L-NAME/ } \\
\text { salt or DOC/salt macro- } \\
\text { phage recruitment } \\
\text { Required for L-NAME/Ang II } \\
\text { macrophage recruitment }\end{array}$ \\
\hline Cardiac function & & & DOC/salt-positive inotropy & \\
\hline $\begin{array}{l}\text { Vascular tone and } \\
\text { contraction }\end{array}$ & $\begin{array}{l}\text { Vascular myogenic } \\
\text { tone } \\
\text { Ang II vascular } \\
\text { contraction }\end{array}$ & & & \\
\hline Oxidative stress & $\begin{array}{l}\text { Ang II oxidative } \\
\text { stress }\end{array}$ & & & \\
\hline Vascular stiffness & $\begin{array}{l}\text { Aldo/salt increase } \\
\text { in vascular } \\
\text { stiffness }\end{array}$ & & & \\
\hline $\begin{array}{l}\text { Endothelial } \\
\text { dysfunction }\end{array}$ & & $\begin{array}{l}\text { Aldo-impaired endothelial } \\
\text { NO function } \\
\text { Aldo-induced endothelial } \\
\text { dysfunction in obesity }\end{array}$ & & \\
\hline
\end{tabular}

Aldo, aldosterone; Ang II, angiotensin II; BP, blood pressure; DOC, deoxycorticosterone; L-NAME, L-NG-nitroarginine methyl ester; NO, nitric oxide; empty cells indicate that the parameter was not tested.

actively involved in numerous pathological conditions including atherosclerosis, inflammation and tissue remodelling. The endothelium expresses MR, GR and HSD2 (HSD11B2) all of which drive numerous physiological and pathological functions in the vascular wall. Clinical and experimental studies depict the effect of aldosterone on the endothelium. Hyperaldosteronism, as a consequence of an aldosterone-producing adrenal adenoma, hypertension or congestive heart failure, is associated with impaired vascular reactivity (Blacher et al. 1997, Duprez et al. 1998).

\section{Endothelial cell MR and inflammation}

Endothelial cells actively regulate both acute and chronic vascular inflammatory processes by the secretion of vasoactive agents and expression of adhesion molecules (Pober \& Sessa 2007). In a mouse model of atherosclerosis (Apoe-deficient mice), which is characterised by an inflammatory response in which monocyte-derived macrophages and endothelial cells play a central role, antagonising the MR reduces oxidative stress and inflammation (Suzuki et al. 2006). In vitro, aldosterone activation of MR in endothelial cells specifically modulates expression of intercellular adhesion molecule 1 (ICAM1) and promotes leukocyte adhesion, highlighting the importance of MR in macrophage recruitment (Caprio et al. 2008). This notion is further supported in vivo, with deletion of the MR from endothelial cells protecting against DOC/salt-induced macrophage recruitment and elevated vascular ICAM1 expression (Rickard et al. 2014).

It is important to note that to date, endothelial cell MR-null mice have been generated using the Tie2 (Tek) promoter to drive Cre expression in endothelial cells. Given that Tie2 is also expressed in myeloid cells, some degree of loss of MR expression in myeloid cells is expected, although this differs considerably between studies (Schafer et al. 2013, 2014). As discussed below, however, the phenotype observed in macrophage-specific MR-null mice (LysM Cre) in terms of cardiovascular protection and blood pressure regulation is significantly different from that observed in endothelial cell MR-null mice (Tie2) (Rickard et al. 2009, Rickard et al. 2014).

\section{Endothelial cell MR and endothelial dysfunction}

Endothelial dysfunction is characterised by impaired endothelial cell NO production and bioavailability, increased permeability, altered endothelium-mediated vasodilation,

Published by Bioscientifica Ltd 
increased vascular reactivity, platelet activation and enhanced thrombogenicity (Endemann \& Schiffrin 2004). A number of clinical and experimental animal studies have demonstrated that aldosterone impairs vascular reactivity, although the precise mechanisms responsible are largely unknown. Aldosterone increases endothelial cell stiffness, which, in turn, reduces NO release (Oberleithner 2005). Increased production of reactive oxygen species (ROS) by endothelial NO synthase (eNOS) uncoupling contributes to the pathology in angiotensin II and DOCAsalt-treated hypertensive rats (Mollnau et al. 2002, Landmesser et al. 2003).

We have recently shown that, in mice, aldosterone impairs endothelial NO function in small resistance-like mesenteric arteries in both WT and endothelial cell MR-null mice (Rickard et al. 2014). These findings suggest that endothelial cell MRs are unlikely to contribute to MR-dependent endothelial dysfunction in resistance arteries and are consistent with the equivalent blood pressure elevation in response to DOC/salt with both genotypes. By contrast, aldosterone impaired endothelial NO function in the aorta from WT mice only, supporting a role for endothelial cell MR in endothelial dysfunction in larger conduit arteries.

Obesity is a major risk factor for hypertension and cardiovascular disease. The importance of endothelial cell MR in obesity-induced endothelial dysfunction has recently been described (Schafer et al. 2013). In dietinduced obese mice, eplerenone treatment prevented the impaired endothelium-dependent relaxation in response to acetylcholine, reduced the expression of pro-oxidative $\mathrm{NADPH}$ oxidase and increased the expression of antioxidant genes. Specifically, exploring the role of endothelial cell MR signalling in diet-induced obesity, Schäfer et al. (2013) demonstrated that specific deletion of MR from endothelial cells prevents obesity and aldosterone-induced endothelial dysfunction without affecting glucose tolerance and pro-inflammatory activity in white adipose tissue. Moreover, endothelial cell MR activity plays an important role in endothelial dysfunction by increasing endothelial p22phox expression.

Experimental animal studies suggest that aldosterone exerts prothrombotic actions by enhancing platelet activation and reducing fibrinolysis, and that MR antagonism can block these effects (Schafer et al. 2003, 2010, Bodary et al. 2006, Stankiewicz et al. 2007, Gromotowicz et al. 2011). Interestingly, MR signalling specifically in endothelial cells has recently been shown to reduce atrial thrombus formation in mice overexpressing MR conditionally in endothelial cells (Lagrange et al. 2014). The authors propose a hypothesis that aldosterone-activated endothelial cell MR possesses antithrombotic properties in healthy vessels, while aldosterone acts synergistically with endothelial injury to exert prothrombotic effects (Newfell et al. 2011).

\section{Endothelial cell MR and blood pressure regulation}

Endothelial dysfunction is associated with the pathophysiology of hypertension. A significant proportion of patients with stage I essential hypertension exhibit impaired small artery vasodilation (Park \& Schiffrin 2001). Increased production of ROS by eNOS uncoupling has been demonstrated in a number of models of hypertension, including rats treated with peroxynitrite, which degrades the eNOS cofactor BH4, spontaneously hypertensive rats and angiotensin II or DOCA-salt-treated hypertensive rats. In DOCA-salt-induced hypertensive rats, it has been proposed that activation of NADPH oxidases provides the initial source of superoxide, which then reacts with $\mathrm{BH} 4$ and reduces $\mathrm{BH} 4$ levels. The loss of $\mathrm{BH} 4$ alters the function of eNOS, leading to reduced NO and elevated ROS production. In these rats, treatment with $\mathrm{BH} 4$ prevents eNOS uncoupling and reduces the blood pressure increase, suggesting that eNOS uncoupling contributes to the pathology of MR-induced hypertension (Fig. 1).

Interestingly, endothelial cell MR-null mice are not protected against DOC/salt-induced blood pressure elevation, suggesting that MR in other cell types of the myocardium regulates blood pressure in this model (Rickard et al. 2014). These data, together with the reduced fibrosis in endothelial cell MR-null mice, provide further support for the well-defined concept that MR-mediated fibrosis and hypertrophy are independent of changes in blood pressure (Rickard et al. 2014).

\section{Endothelial cell MR and tissue remodelling}

Endothelial cells appear to be involved in the early pathological events of cardiac tissue remodelling. Activated endothelial cells release profibrotic mediators, inducing fibroblast activation and increased collagen deposition. Moreover, endothelial-mesenchymal transition, a recently recognised type of cellular transition, suggests that endothelial cells may play an important role in the pathogenesis of cardiac tissue fibrosis (Piera-Velazquez et al. 2011). Endothelial-mesenchymal transition is a process in which endothelial cells lose their specific markers and gain a mesenchymal or myofibroblastic phenotype. To date, the importance of the MR in endothelial-mesenchymal transition has not been defined. Interestingly, endothelial cell-specific MR knockout mice

Published by Bioscientifica Ltd. 


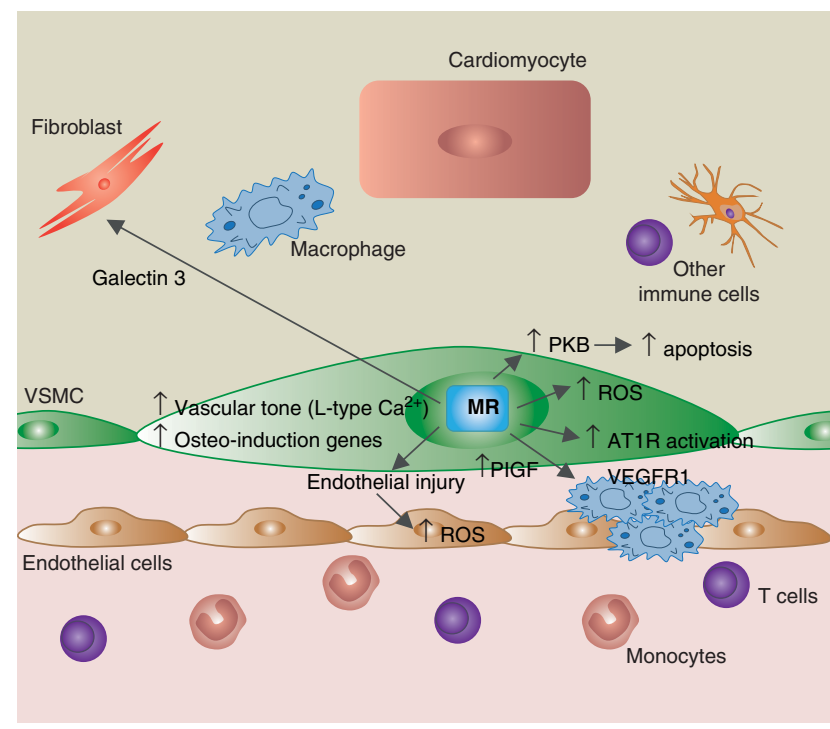

Figure 1

Mineralocorticoid receptor activity in vascular smooth muscle cells. Mineralocorticoid receptor signalling in VSMCs alters vascular function via several mechanisms including PIGF signalling, VEGFR1 signalling, Mac2 activity, increasing ROS and activation of the AT1R. MR in VSMCs increases vascular tone via regulation of L-type calcium channels and contributes to endothelial cell injury. VSMCs, vascular smooth muscle cells; MR, mineralocorticoid receptor; Mac2, galactin 3; VEGFR1, vascular endothelial growth factor receptor 1; PKB, protein kinase B; PIGF, placental growth factor; ROS, reactive oxygen species; AT1R, angiotensin II receptor type 1.

are protected against DOC/salt-induced fibrosis (Rickard et al. 2014). As noted earlier, DOC-induced inflammatory cell infiltrate is also attenuated in these mice, suggesting that the cardiac protection observed in this model may be primarily due to a reduced inflammatory response (Rickard et al. 2009). Further studies to explore the role of the MR and the intracellular interactions within the myocardium are required to understand the mechanisms responsible for DOC/salt-induced cardiac fibrosis. MR-dependent signalling pathways in the endothelial cells are summarised in Fig. 2.

\section{The MR in cardiomyocytes}

The MR was identified in cardiomyocytes over two decades ago and, as noted earlier, acts as a high-affinity cortisol receptor, given that HSD2 expression is absent (Pearce \& Funder 1988, Iqbal et al. 2014). Although cortisol is the predominant ligand for cardiac MR, aldosterone can be considered to play a physiological role in the maintenance of cardiac output as part of the response to volume depletion. The cardiac MR, however, is best known for its role in cardiac tissue remodelling processes, the mechanisms of which are discussed in this section.

\section{Cardiomyocyte MR, tissue remodelling and heart failure}

The recent generation of cardiomyocyte MR-null mice, using either the myosin light chain 2a (Mlc2a (Myl7)) or the Mlc2v (Myl2) promoter, has facilitated the direct investigation of MR in cardiomyocytes in vivo. Fraccarollo et al. (2011) demonstrated that cardiomyocyte-specific MR deficiency improved infarct healing and prevented progressive adverse cardiac remodelling, cardiac hypertrophy of the surviving tissue, contractile dysfunction and gene expression profiles in ischaemic heart failure (Fraccarollo et al. 2011). Specifically, early tissue changes after infarct were significantly improved in cardiomyocyte MR-null mice, including increased scar thickness in the infarct zone and increased capillary density in the viable tissue. Tissue inflammation and markers of apoptosis were similarly improved in the first 7 days after infarct, compared with WT mice. These early improvements were associated with marked improvements in left ventricular filling pressures, left ventricular end diastolic and end systolic volumes and left ventricular ejection fraction in cardiomyocyte MR-null mice after infarct when compared with WT mice. These data underscore the importance of cardiomyocyte MR for heart failure onset

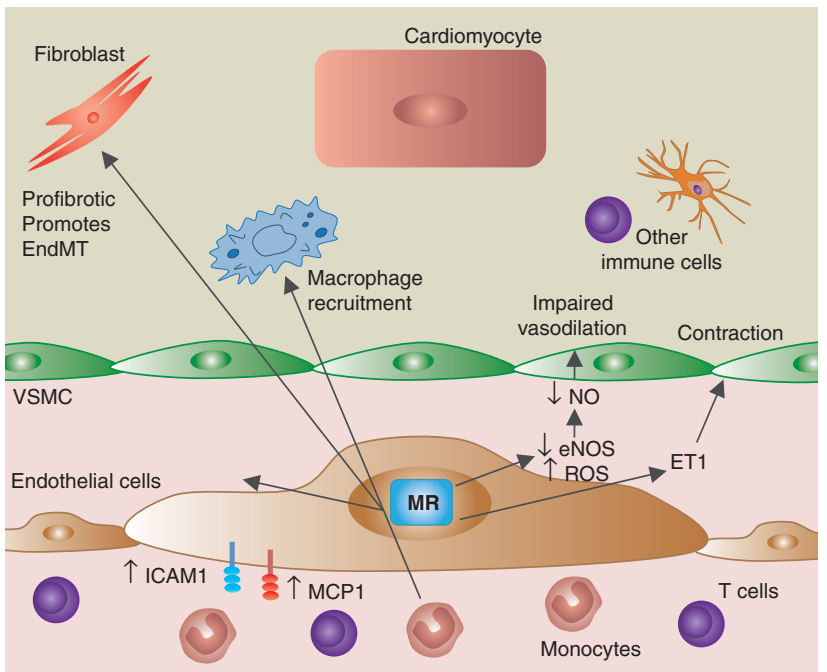

\section{Figure 2}

Mineralocorticoid receptor activity in endothelial cells. Mineralocorticoid receptor signalling in endothelial cells modulates ICAM1 and MCP1 expression, exerts profibrotic effects, stimulates macrophage recruitment to the myocardium and promotes EndMT. Endothelial cell MR alters vascular tone by increasing VSMC contraction via ET1 and impairing vasodilation by decreasing NO production. VSMCs, vascular smooth muscle cells; MR, mineralocorticoid receptor; EndMT, endothelial-to-mesenchymal transition; NO, nitric oxide; eNOS, endothelial nitric oxide synthase; ROS, reactive oxygen species; ET1, endothelin 1; MCP1, monocyte chemotactic protein 1; ICAM1, intracellular adhesion molecule 1.

Published by Bioscientifica Ltd. 
and development and, taken together with previous pharmacological studies, provide strong evidence that cardiac dysfunction and failure can be limited by early initiation of MR blockade after infarct. Notably, immediate MR blockade improves myocardial infarct healing by modulation of the inflammatory response (Fraccarollo et al. 2008). Loss of the cardiomyocyte MR was also protective in the transaortic constriction model of pressure overload (Lother et al. 2011). Cardiomyocyte MR-null mice were protected from cardiac dilatation and failure, demonstrating a significantly higher left ventricular ejection fraction compared with control mice. The authors suggested that a mild increase in cardiac wall thickness at baseline in the mutant mice (which was not detected in the previous study) may have contributed to the reduction in left ventricular wall tension after pressure overload. However, loss of cardiomyocyte MR did not prevent the development of cardiac hypertrophy, fibrosis, apoptosis index or inflammatory response after pressure overload, suggesting that the cardiomyocyte MR does not play a universal role in the onset of cardiac remodelling.

Studies from our laboratory investigated cardiovascular responses to the DOC/salt model of cardiac fibrosis and hypertension in mice null for cardiomyocyte MR (Rickard et al. 2012). We showed that activation of the cardiomyocyte MR was required from the primary inflammatory response and recruitment of inflammatory cells to the heart. As described in detail below, blocking the recruitment of macrophages to the myocardium is protective in itself (Shen et al. 2014). However, this model allowed for the identification of important signalling intermediates that were selectively regulated by the cardiomyocyte MR and point to a direct role for cardiomyocyte MR in DOC/salt-induced cardiac tissue remodelling. Selective regulation of matrix metallopeptidase 2/matrix metallopeptidase 9 activity and the transforming growth factor beta (TGF $\beta$ )-connective tissue growth factor (CTGF) profibrotic pathway by the MR in these cells suggest potential mechanisms for the cardioprotective effects of the loss of MR signalling. The TGF $\beta-$ CTGF inhibitor decorin was also significantly upregulated in cardiomyocyte MR-null mice, thus it is possible that lower collagen levels may reflect an increase in inhibitors of the fibrotic process in the MR-null cardiomyocytes.

Further insights into the role of the cardiomyocyte MR in cardiac function and pathology have been identified in vivo in an earlier work on transgenic MR-overexpressing mice. First, genome-wide analyses of the MR-overexpressing heart, untreated and treated with aldosterone for 7 days, offer some insight into selective aldosterone-MR-regulated genes in cardiomyocytes (Messaoudi et al. 2013). CTGF was one example of an MR target gene linked to cardiac remodelling that showed aldosterone-dependent regulation despite higher levels of intracellular GRs. Neutrophil gelatinase-associated lipocalin is another novel MR target in the cardiovascular system that may serve as a useful biomarker for MR-dependent cardiac dysfunction (Latouche et al. 2012). Notably, these mice did not show increased fibrosis, inflammation or apoptosis in the myocardium, supporting the hypothesis that an elevated sodium status is required for MR-mediated cardiac pathology.

\section{Cardiomyocyte MR and contractile function}

An important observation in these studies is that the MR does not appear critical for normal cardiac development nor cardiac function in the unchallenged state. Baseline data from all three studies in cardiomyocyte MR-null mice showed normal systolic and diastolic functions and chamber diameters. Deletion of cardiac MR signalling did, however, result in the loss of the expected chronotropic and inotropic responses to DOC/salt (Rickard et al. 2012). These data are consistent with previous studies showing aldosterone-dependent increased fractional shortening of cardiomyocytes and chronotropic responses in isolated cardiomyocytes (Bravo et al. 1977, Barbato et al . 2004, Rossier et al. 2010). Rossier et al. (2008) have also shown the MR and GR to have additive chronotropic effects on the cardiomyocytes and that these can be modulated by the oxidative status of the cell. Notably, in cells expressing the MR alone, cortisol requires the presence of an oxidant to have an effect. To produce these responses, the MR and GR act to regulate T-type and L-type calcium channel expression (current amplitude) and activity (frequency) and may therefore also enhance the pro-arrhythmogenic potential of the myocardium (Rossier et al. 2008).

Conditional cardiac-specific overexpression of the human MR in mice also produced a high rate of sudden cardiac death (Ouvrard-Pascaud et al. 2005). Downregulation of the potassium transient outward current (Ito), an increase in the L-type calcium current (ICa) and the resultant prolonged ventricular repolarisation and severe ventricular arrhythmias are very likely to account for this phenotype. NOX-dependent, ROS-mediated coronary endothelial dysfunction are also evident in cardiomyocyte-specific MR overexpression indicating the importance of cell-cell signalling and the broader implications for cardiac MR activation in one cell type within the heart (Favre et al. 2011). As noted by the authors, the pro-arrhythmic effects

Published by Bioscientifica Ltd 


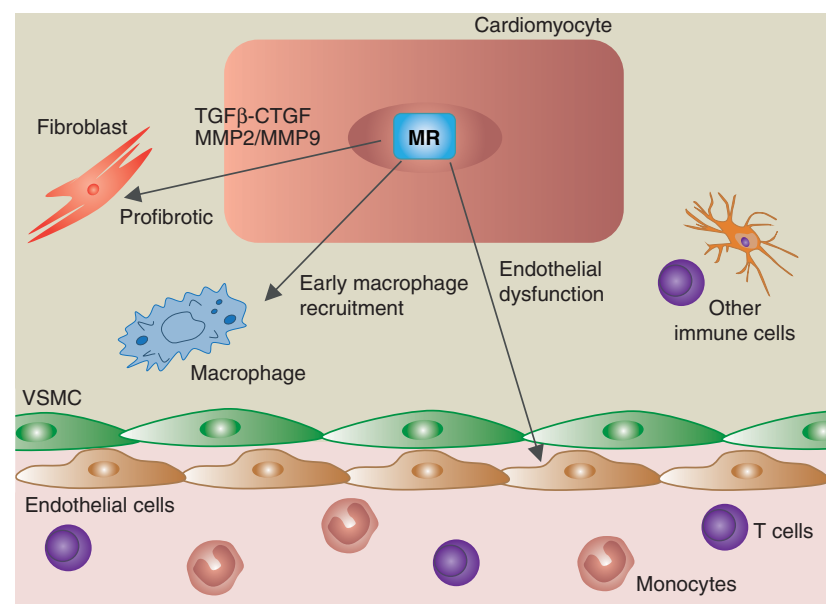

\section{Figure 3}

Mineralocorticoid receptor activity in cardiomyocytes. Mineralocorticoid receptor signalling in cardiomyocytes stimulates increase in collagen deposition via the selective regulation of MMP2/MMP9 activity and the TGF $\beta$-CTGF pathway. MR in cardiomyocytes also contributes to early macrophage recruitment and endothelial dysfunction. VSMCs, vascular smooth muscle cells; MR, mineralocorticoid receptor; TGF $\beta$, transforming growth factor beta; CTGF, connective tissue growth factor; MMP2, matrix metallopeptidase 2; MMP9, matrix metallopeptidase 9.

of the MR may reflect an important component of the protective effects of MR antagonists, which include decreased sudden death (Pitt et al. 1999, 2001).

The cellular mechanisms involved in MR regulation of cardiomyocyte function are illustrated in Fig. 3.

\section{MR signalling in inflammatory cells}

Research over the past two decades has illustrated the remarkable impact of the immune response to the pathogenesis of cardiovascular disease (Mann 2011, Schiffrin 2014). The immune system comprises two components: the innate and the adaptive immune responses. The innate immune response employs a defined set of germline-encoded pattern-recognition receptors, such as toll-like receptors, NOD-like receptors, RIG1-like receptors and C-type lectin, which recognise pathogen-associated molecular patterns or damage-associated molecular patterns. The adaptive immune response relies on the generation of antigen receptors on T- and B-lymphocytes and the subsequent activation and clonal expansion of cells carrying the appropriate antigen-specific receptors.

\section{Macrophage MR and inflammation}

Macrophages are key regulators of the initiation and progression of many pathologies including hypertension and cardiovascular disease (Rickard \& Young 2009). They exhibit a high level of functional plasticity, which is predominantly controlled by signals from the microenvironment in which they reside. Signals from the tissue microenvironment dictate the specific phenotype they acquire, which lies along a spectrum broadly defined as classically (M1) and alternatively (M2) activated macrophages (Goerdt et al. 1999, Gordon 2003, Martinez et al. 2008). Classical activation refers to stimulation by interferon $\gamma$ and lipopolysaccharide, whereas alternative activation requires interleukins (IL10, IL4 and IL13), TGF $\beta$ or GRs to promote an M2-like phenotype. M1-like macrophages produce pro-inflammatory cytokines, chemokines and oxidative intermediates. By contrast, an M2-like phenotype is typically associated with anti-inflammatory signals, tissue remodelling and angiogenesis.

Macrophages express MR and GR but not HSD2; hence, under normal circumstances, the MR in macrophages is occupied by GRs (Lim et al. 2007). Corticosteroid receptor signalling in macrophages and other immune cells (microglia) appear to be mediated in a concentrationdependent manner. In microglia, low-dose corticosteroids $(1 \mathrm{nM})$ promote inflammatory gene expression via MR, whereas the immunosuppressive effects of higher dose corticosteroid (100 $\mathrm{nM}$ ) are conferred through GR (Tanaka et al. 1997).

It is well accepted that cardiac tissue inflammation plays an integral role in the initiation and progression of MR-mediated cardiac pathology. Early studies demonstrated elevated myocardial and/or vascular expression of inflammatory mediators after just one week of mineralocorticoid treatment (Fujisawa et al. 2001, Rocha et al. 2002, Young et al. 2003). Moreover, the critical role of inflammation in hypertension is also becoming increasingly apparent (Schiffrin 2014).

With the use of macrophage-specific MR-null mice, we identified a critical role for macrophage MR signalling in both mineralocorticoid-dependent and -independent models of cardiac pathology (Rickard et al. 2009, Bienvenu et al. 2012). Deletion of MR from macrophages altered the baseline expression of a number of pro-inflammatory genes, suggesting that, under normal circumstances, GRoccupied MR maintain normal macrophage function. Interestingly, macrophage recruitment was not altered by the loss of macrophage MR signalling in these models, suggesting that the MR in other cardiovascular cell types is responsible for macrophage recruitment in DOC/saltinduced cardiac pathology. As noted earlier, we have recently demonstrated a critical role for endothelial cell MR signalling in DOC/salt-induced macrophage recruitment (Rickard et al. 2014). Usher et al. (2010) expanded

Published by Bioscientifica Ltd. 
upon these findings, demonstrating that macrophage MR is necessary for classical macrophage activation, given that macrophage MR-null mice displayed a transcriptional profile of alternative macrophage activation (Usher et al. 2010). In contrast to what has been observed in response to DOC/salt treatment for 8 weeks, macrophage MR-null mice were protected against NG-nitro-L-arginine methyl ester (L-NAME)/angiotensin II-induced macrophage recruitment (Usher et al. 2010).

\section{T lymphocytes, MR and cardiac pathology}

In addition to macrophages, a number of other immune cells are increasingly recognised as playing an important role in the pathophysiology of cardiovascular disease and hypertension. $T$ lymphocytes are adaptive immune cells that play a central role in orchestrating the immune response. The expression of MR in mouse splenic $\mathrm{T}$ lymphocytes was first described over 25 years ago (Armanini et al. 1985). T lymphocytes lack HSD2, thus MRs in T lymphocytes are hypothesised receptors for cortisol. A number of studies have implicated T lymphocytes in MR-mediated pathology. Mice lacking $\mathrm{T}$ and B lymphocytes $\left(\mathrm{Rag}^{-/-}\right)$demonstrate a blunted blood pressure increase to both angiotensin II and DOCAsalt-induced hypertension (Guzik et al. 2007). Adoptive transfer of T lymphocytes, but not B-lymphocytes, restores the hypertensive response to angiotensin II and DOCAsalt in Rag1 ${ }^{-/-}$mice, suggesting a role for T lymphocytes in the pathogenesis of hypertension. Furthermore, in vivo studies show that aldosterone can enhance the severity of Th17-mediated autoimmune disease responses, suggesting that MR-mediated inflammation may in part be mediated by amplification of the Th17 immune response (Herrada et al. 2010). This notion is further supported by a recent study in DOCA-salt-treated rats, where MR activation promoted Th17 polarisation and suppressed Treg function (Amador et al. 2014). Despite these recent advances, however, it remains unclear whether the effects of MR signalling on Tlymphocyte polarisation are mediated by MR activation in T lymphocytes or via MR signalling in other inflammatory cells, i.e. macrophages or dendritic cells.

\section{Macrophage MR and cardiac fibrosis}

Macrophages play a key role in fibrotic disease by altering the balance between matrix synthesis and degradation, via the secretion of various proteases and cytokines (Lupher \& Gallatin 2006, Wynn 2008). With the use of macrophagespecific MR-null mice, we identified a critical role for macrophage MR signalling in both mineralocorticoiddependent and -independent models of cardiac fibrosis and profibrotic gene expression (Rickard et al. 2009, Bienvenu et al. 2012). The importance of macrophage MR in L-NAME/angiotensin II-induced cardiac hypertrophy, fibrosis and vascular damage has also been demonstrated (Usher et al. 2010).

\section{Macrophage MR and stroke}

Immune cells play a central role in ischaemic brain injury. In experimental models of ischaemic stroke, MR antagonists reduce the infarct size and neurological deficit, without altering blood pressure (Dorrance et al. 2001, Iwanami et al. 2007, Oyamada et al. 2008). In a mouse model of transient middle cerebral artery occlusion, deletion of MR from macrophages reduced infarct volume and inflammation and improved neurological function (Frieler et al. 2012). Interestingly, in contrast to MR antagonists, which were protective against both transient and permanent occlusions in WT mice, specific deletion of MR from macrophages does not protect against permanent middle cerebral artery occlusion (Frieler et al. 2012). While the mechanism responsible for this difference in protection is unknown, it supports the notion that macrophages, and the MR in macrophages, play an important role in the initial response to reperfusion injury. These and the aforementioned pathways regulated by the MR in macrophages are illustrated in Fig. 4 .

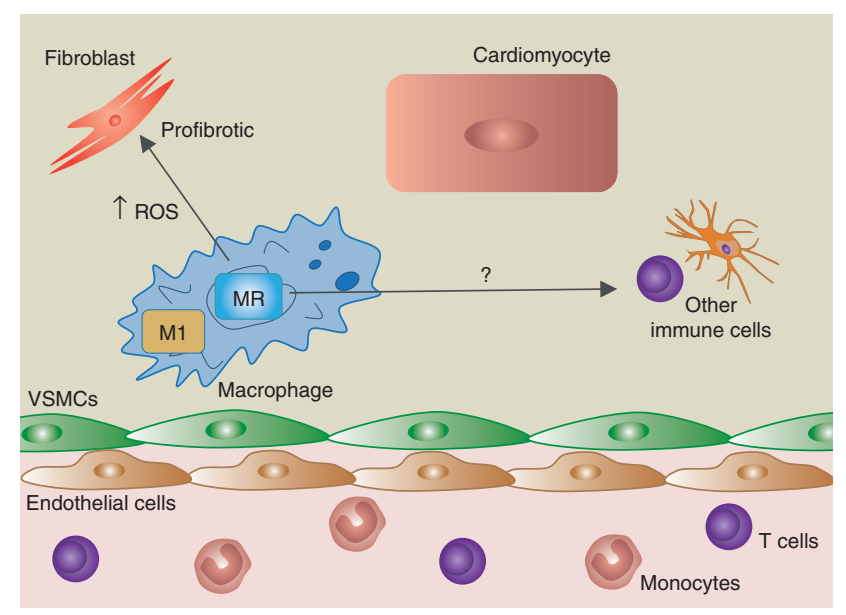

Figure 4

Mineralocorticoid receptor activity in macrophages. Mineralocorticoid receptor signalling in macrophages contributes to fibrosis by increasing ROS. Macrophage MRs are necessary for classical macrophage activation. VSMCs, vascular smooth muscle cells; MR, mineralocorticoid receptor; ROS, reactive oxygen species; M1, classically activated macrophages.

Published by Bioscientifica Ltd. 


\section{Conclusion and perspectives}

Pharmacological studies over the $20+$ years following Brilla \& Weber's (1992) publication describing the profibrotic effects of aldosterone plus salt, have defined the important role of MR in cardiac fibrosis, inflammation and vascular dysfunction. Collectively, these studies paved the way for a series of large-scale clinical trials of MR antagonists for heart failure management (Pitt et al. 1999, 2001, Zannad et al. 2011). The outcomes of these trials in turn have validated MR activity as an independent risk factor for cardiovascular disease and led to the development of eplerenone, which has a significantly greater specificity for the MR.

The recent series of studies using transgenic MR overexpressing or cell-selective MR-null mice described in this review have represented a new direction in understanding the role of MR in cardiovascular disease and provide a significant advantage over earlier pharmacological studies by allowing the dissection of unique cellular actions of MR. The overall cardiovascular 'outcome' of enhanced MR signalling is a composite of both rapid second messenger signalling (EGFR, $\mathrm{Na} / \mathrm{K} / 2 \mathrm{Cl}$ cotransporter, etc.) and gene/protein expression (calcium channels, growth factors, cytokines, etc.), which represent both compensatory physiological responses and defined pathological pathways. Taken together, these studies serve to illustrate the complex and coordinated role of MR in both the regulation of plasma volume homoeostasis and the development of cardiovascular disease.

Whether or not therapeutically silencing MR in one cell type alone will be sufficient to protect against cardiovascular diseases remains unclear. Future studies are required for exploring MR-dependent cell-cell interactions in the initiation and progression of cardiovascular disease, which is an important step towards realising this goal.

\section{Declaration of interest}

The authors declare that there is no conflict of interest that could be perceived as prejudicing the impartiality of this review.

\section{Funding}

This work was supported by the Australia Early Career Fellowship from the National Health and Medical Research Council to A J R. MIMR-PHI is supported by the Victorian Government's Operational Infrastructure Support Program.

\section{Acknowledgements}

The authors are grateful to Prof. Peter J Fuller and Dr Jimmy Z Shen for their helpful discussions and assistance in preparing the manuscript.

\section{References}

Amador CA, Barrientos V, Pena J, Herrada AA, Gonzalez M, Valdes S, Carrasco L, Alzamora R, Figueroa F, Kalergis AM et al. 2014 Spironolactone decreases DOCA-salt-induced organ damage by blocking the activation of T helper 17 and the downregulation of regulatory T lymphocytes. Hypertension 63 797-803. (doi:10.1161/HYPERTENSIONAHA.113.02883)

Armanini D, Strasser T \& Weber PC 1985 Characterization of aldosterone binding sites in circulating human mononuclear leukocytes. American Journal of Physiology 248 E388-E390.

Barbato JC, Rashid S, Mulrow PJ, Shapiro JI \& Franco-Saenz R 2004 Mechanisms for aldosterone and spironolactone-induced positive inotropic actions in the rat heart. Hypertension 44 751-757. (doi:10.1161/01.HYP.0000144466.11568.7e)

Bienvenu LA, Morgan J, Rickard AJ, Tesch GH, Cranston GA, Fletcher EK, Delbridge LM \& Young MJ 2012 Macrophage mineralocorticoid receptor signaling plays a key role in aldosterone-independent cardiac fibrosis. Endocrinology 153 3416-3425. (doi:10.1210/en.2011-2098)

Blacher J, Amah G, Girerd X, Kheder A, Ben Mais H, London GM \& Safar ME 1997 Association between increased plasma levels of aldosterone and decreased systemic arterial compliance in subjects with essential hypertension. American Journal of Hypertension 10 1326-1334. (doi:10.1016/S0895-7061(97)00301-4)

Bodary PF, Sambaziotis C, Wickenheiser KJ, Rajagopalan S, Pitt B \& Eitzman DT 2006 Aldosterone promotes thrombosis formation after arterial injury in mice. Arteriosclerosis, Thrombosis, and Vascular Biology 26 233. (doi:10.1161/01.ATV.0000195782.07637.44)

Bravo EL, Tarazi RC \& Dustan HP 1977 Multifactorial analysis of chronic hypertension induced by electrolyte-active steroids in trained, unanesthetized dogs. Circulation Research 40 I140-I145.

Brilla CG \& Weber KT 1992 Mineralocorticoid excess, dietary sodium, and myocardial fibrosis. Journal of Laboratory and Clinical Medicine 120 893-901.

Caprio M, Newfell BG, la Sala A, Baur W, Fabbri A, Rosano G, Mendelsohn ME \& Jaffe IZ 2008 Functional mineralocorticoid receptors in human vascular endothelial cells regulate intercellular adhesion molecule-1 expression and promote leukocyte adhesion. Circulation Research 102 1359-1367. (doi:10.1161/CIRCRESAHA.108.174235)

Chantong B, Kratschmar DV, Nashev LG, Balazs Z \& Odermatt A 2012 Mineralocorticoid and glucocorticoid receptors differentially regulate $\mathrm{NF}-\kappa \mathrm{B}$ activity and pro-inflammatory cytokine production in murine BV-2 microglial cells. Journal of Neuroinflammation 9 260. (doi:10.1186/ 1742-2094-9-260)

Christ M, Wehling M, Kirsch E, Viengchareun S, Zennaro MC \& Lombes M 2005 Enhancement of $\beta$-adrenergic cAMP-signaling by the mineralocorticoid receptor. Molecular and Cellular Endocrinology 231 23-31. (doi:10.1016/j.mce.2004.12.004)

Crabbe J 1963 Site of action of aldosterone on the bladder of the toad. Nature 200 787-788. (doi:10.1038/200787a0)

Dorrance AM, Osborn HL, Grekin R \& Webb RC 2001 Spironolactone reduces cerebral infarct size and EGF-receptor mRNA in stroke-prone rats. American Journal of Physiology. Regulatory, Integrative and Comparative Physiology 281 R944-R950.

Duprez DA, De Buyzere ML, Rietzschel ER, Taes Y, Clement DL, Morgan D \& Cohn JN 1998 Inverse relationship between aldosterone and large artery compliance in chronically treated heart failure patients. European Heart Journal 19 1371-1376. (doi:10.1053/euhj.1998.1099)

Ehsan A, McGraw AP, Aronovitz MJ, Galayda C, Conte MS, Karas RH \& Jaffe IZ 2013 Mineralocorticoid receptor antagonism inhibits vein graft remodeling in mice. Journal of Thoracic and Cardiovascular Surgery 145 1642-1649, 1649 e1641. (doi:10.1016/j.jtcvs.2012.08.007)

Endemann DH \& Schiffrin EL 2004 Nitric oxide, oxidative excess, and vascular complications of diabetes mellitus. Current Hypertension Reports 6 85-89. (doi:10.1007/s11906-004-0081-x) 
Favre J, Gao J, Zhang AD, Remy-Jouet I, Ouvrard-Pascaud A, Dautreaux B, Escoubet B, Thuillez C, Jaisser F \& Richard V 2011 Coronary endothelial dysfunction after cardiomyocyte-specific mineralocorticoid receptor overexpression. American Journal of Physiology. Heart and Circulatory Physiology 300 H2035-H2043. (doi:10.1152/ajpheart.00552.2010)

Fiebeler A, Schmidt F, Muller DN, Park JK, Dechend R, Bieringer M, Shagdarsuren E, Breu V, Haller H \& Luft FC 2001 Mineralocorticoid receptor affects AP-1 and nuclear factor-kappab activation in angiotensin II-induced cardiac injury. Hypertension 37 787-793. (doi:10.1161/01.HYP.37.2.787)

Fishman AP 1982 Endothelium: a distributed organ of diverse capabilities. Annals of the New York Academy of Sciences 401 1-8. (doi:10.1111/ j.1749-6632.1982.tb25702.x)

Fraccarollo D, Galuppo P, Schraut S, Kneitz S, van Rooijen N, Ertl G \& Bauersachs J 2008 Immediate mineralocorticoid receptor blockade improves myocardial infarct healing by modulation of the inflammatory response. Hypertension 51 905-914. (doi:10.1161/HYPERTENSIONAHA.107.100941)

Fraccarollo D, Berger S, Galuppo P, Kneitz S, Hein L, Schutz G, Frantz S, Ertl G \& Bauersachs J 2011 Deletion of cardiomyocyte mineralocorticoid receptor ameliorates adverse remodeling after myocardial infarction. Circulation 123 400-408. (doi:10.1161/CIRCULATIONAHA. 110.983023)

Frieler RA, Ray JJ, Meng H, Ramnarayanan SP, Usher MG, Su EJ, Berger S, Pinsky DJ, Lawrence DA, Wang MM et al. 2012 Myeloid mineralocorticoid receptor during experimental ischemic stroke: effects of model and sex. Journal of the American Heart Association 1 e002584. (doi:10.1161/JAHA.112.002584)

Fujisawa G, Dilley R, Fullerton MJ \& Funder JW 2001 Experimental cardiac fibrosis: differential time course of responses to mineralocorticoid-salt administration. Endocrinology 142 3625-3631. (doi:10.1210/ endo.142.8.8339)

Galmiche G, Pizard A, Gueret A, El Moghrabi S, Ouvrard-Pascaud A, Berger S, Challande P, Jaffe IZ, Labat C, Lacolley P et al. 2014 Smooth muscle cell mineralocorticoid receptors are mandatory for aldosterone-salt to induce vascular stiffness. Hypertension 63 520-526. (doi:10.1161/ HYPERTENSIONAHA.113.01967)

Gekle M, Freudinger R, Mildenberger S, Schenk K, Marschitz I \& Schramek H 2001 Rapid activation of $\mathrm{Na}+/ \mathrm{H}+-$ exchange in MDCK cells by aldosterone involves MAP-kinase ERK1/2. Pflügers Archiv 441 781-786.

Goerdt S, Politz O, Schledzewski K, Birk R, Gratchev A, Guillot P, Hakiy N, Klemke CD, Dippel E, Kodelja V et al. 1999 Alternative versus classical activation of macrophages. Pathobiology 67 222-226. (doi:10.1159/ 000028096)

Gordon S 2003 Alternative activation of macrophages. Nature Reviews. Immunology 3 23-35. (doi:10.1038/nri978)

Gromotowicz A, Szemraj J, Stankiewicz A, Zakrzeska A, Mantur M, Jaroszewicz E, Rogowski F \& Chabielska E 2011 Study of the mechanisms of aldosterone prothrombotic effect in rats. Journal of Renin-Angiotensin-Aldosterone System 12 430-439. (doi:10.1177/ 1470320310397405)

Gros R, Ding Q, Sklar LA, Prossnitz EE, Arterburn JB, Chorazyczewski J \& Feldman RD 2011 GPR30 expression is required for the mineralocorticoid receptor-independent rapid vascular effects of aldosterone. Hypertension 57 442-451. (doi:10.1161/HYPERTENSIONAHA.110.161653)

Grossmann C, Benesic A, Krug AW, Freudinger R, Mildenberger S, Gassner B \& Gekle M 2005 Human mineralocorticoid receptor expression renders cells responsive for nongenotropic aldosterone actions. Molecular Endocrinology 19 1697-1710. (doi:10.1210/me.2004-0469)

Grossmann C, Husse B, Mildenberger S, Schreier B, Schuman K \& Gekle M 2010 Colocalization of mineralocorticoid and EGF receptor at the plasma membrane. Biochimica et Biophysica Acta 1803 584-590. (doi:10.1016/j.bbamcr.2010.02.008)

Grundy HM, Simpson SA \& Tait JF 1952 Isolation of a highly active mineralocorticoid from beef adrenal extract. Nature 169 795-796. (doi:10.1038/169795a0)
Guzik TJ, Hoch NE, Brown KA, McCann LA, Rahman A, Dikalov S, Goronzy J, Weyand C \& Harrison DG 2007 Role of the T cell in the genesis of angiotensin II induced hypertension and vascular dysfunction. Journal of Experimental Medicine 204 2449-2460. (doi:10.1084/ jem.20070657)

Haseroth K, Gerdes D, Berger S, Feuring M, Gunther A, Herbst C, Christ M \& Wehling M 1999 Rapid nongenomic effects of aldosterone in mineralocorticoid-receptor-knockout mice. Biochemical and Biophysical Research Communications 266 257-261. (doi:10.1006/bbrc.1999.1771)

Hashikabe Y, Suzuki K, Jojima T, Uchida K \& Hattori Y 2006 Aldosterone impairs vascular endothelial cell function. Journal of Cardiovascular Pharmacology 47 609-613. (doi:10.1097/01.fjc.0000211738.63207.c3)

Herrada AA, Contreras FJ, Marini NP, Amador CA, Gonzalez PA, Cortes CM, Riedel CA, Carvajal CA, Figueroa F, Michea LF et al. 2010 Aldosterone promotes autoimmune damage by enhancing Th17-mediated immunity. Journal of Immunology 184 191-202. (doi:10.4049/ jimmunol.0802886)

Iqbal J, Andrew R, Cruden NL, Kenyon CJ, Hughes KA, Newby DE, Hadoke PW \& Walker BR 2014 Displacement of cortisol from human heart by acute administration of a mineralocorticoid receptor antagonist. Journal of Clinical Endocrinology and Metabolism 99 915-922.

Iwanami J, Mogi M, Okamoto S, Gao XY, Li JM, Min LJ, Ide A, Tsukuda K, Iwai M \& Horiuchi M 2007 Pretreatment with eplerenone reduces stroke volume in mouse middle cerebral artery occlusion model. European Journal of Pharmacology 566 153-159. (doi:10.1016/j.ejphar. 2007.03.043)

Jaffe IZ, Newfell BG, Aronovitz M, Mohammad NN, McGraw AP, Perreault RE, Carmeliet P, Ehsan A \& Mendelsohn ME 2010 Placental growth factor mediates aldosterone-dependent vascular injury in mice. Journal of Clinical Investigation 120 3891-3900. (doi:10.1172/JCI40205)

Karst H, Berger S, Turiault M, Tronche F, Schutz G \& Joels M 2005 Mineralocorticoid receptors are indispensable for nongenomic modulation of hippocampal glutamate transmission by corticosterone. PNAS 102 19204-19207. (doi:10.1073/pnas.0507572102)

Kolla V \& Litwack G 2000 Inhibition of mineralocorticoid-mediated transcription by NF-kappaB. Archives of Biochemistry and Biophysics $\mathbf{3 8 3}$ 38-45. (doi:10.1006/abbi.2000.2045)

Lagrange J, Li Z, Fassot C, Bourhim M, Louis H, Nguyen Dinh Cat A, Parlakian A, Wahl D, Lacolley P, Jaisser F et al. 2014 Endothelial mineralocorticoid receptor activation enhances endothelial protein $\mathrm{C}$ receptor and decreases vascular thrombosis in mice. FASEB Journal $\mathbf{2 8}$ 2062-2072. (doi:10.1096/fj.13-238188)

Landmesser U, Dikalov S, Price SR, McCann L, Fukai T, Holland SM, Mitch WE $\&$ Harrison DG 2003 Oxidation of tetrahydrobiopterin leads to uncoupling of endothelial cell nitric oxide synthase in hypertension. Journal of Clinical Investigation 111 1201-1209. (doi:10.1172/ JCI200314172)

Latouche C, El Moghrabi S, Messaoudi S, Nguyen Dinh Cat A, HernandezDiaz I, Alvarez de la Rosa D, Perret C, Lopez Andres N, Rossignol P, Zannad F et al. 2012 Neutrophil gelatinase-associated lipocalin is a novel mineralocorticoid target in the cardiovascular system. Hypertension 59 966-972. (doi:10.1161/HYPERTENSIONAHA.111.187872)

Lim HY, Muller N, Herold MJ, van den Brandt J \& Reichardt HM 2007 Glucocorticoids exert opposing effects on macrophage function dependent on their concentration. Immunology 122 47-53. (doi:10.1111/j.1365-2567.2007.02611.x)

Lother A, Berger S, Gilsbach R, Rosner S, Ecke A, Barreto F, Bauersachs J, Schutz G \& Hein L 2011 Ablation of mineralocorticoid receptors in myocytes but not in fibroblasts preserves cardiac function. Hypertension 57 746-754. (doi:10.1161/HYPERTENSIONAHA.110.163287)

Lupher ML Jr \& Gallatin WM 2006 Regulation of fibrosis by the immune system. Advances in Immunology 89 245-288.

Mann DL 2011 The emerging role of innate immunity in the heart and vascular system: for whom the cell tolls. Circulation Research 108 1133-1145. (doi:10.1161/CIRCRESAHA.110.226936) 
Martinez FO, Sica A, Mantovani A \& Locati M 2008 Macrophage activation and polarization. Frontiers in Bioscience 13 453-461. (doi:10.2741/2692)

McCurley A, Pires PW, Bender SB, Aronovitz M, Zhao MJ, Metzger D, Chambon P, Hill MA, Dorrance AM, Mendelsohn ME et al. 2012 Direct regulation of blood pressure by smooth muscle cell mineralocorticoid receptors. Nature Medicine 18 1429-1433. (doi:10.1038/nm.2891)

McEneaney V, Harvey BJ \& Thomas W 2008 Aldosterone regulates rapid trafficking of epithelial sodium channel subunits in renal cortical collecting duct cells via protein kinase D activation. Molecular Endocrinology 22 881-892. (doi:10.1210/me.2007-0225)

McEneaney V, Dooley R, Harvey BJ \& Thomas W 2010 Protein kinase D stabilizes aldosterone-induced ERK1/2 MAP kinase activation in M1 renal cortical collecting duct cells to promote cell proliferation. Journal of Steroid Biochemistry and Molecular Biology 118 18-28. (doi:10.1016/j.jsbmb.2009.09.014)

McGraw AP, BagleyJ, Chen WS, Galayda C, Nickerson H, Armani A, Caprio M, Carmeliet P \& Jaffe IZ 2013 Aldosterone increases early atherosclerosis and promotes plaque inflammation through a placental growth factordependent mechanism. Journal of the American Heart Association 2 e000018. (doi:10.1161/JAHA.112.000018)

Messaoudi S, Gravez B, Tarjus A, Pelloux V, Ouvrard-Pascaud A, Delcayre C, Samuel J, Launay JM, Sierra-Ramos C, Alvarez de la Rosa D et al. 2013 Aldosterone-specific activation of cardiomyocyte mineralocorticoid receptor in vivo. Hypertension 61 361-367. (doi:10.1161/HYPERTENSIONAHA.112.198986)

Mollnau H, Wendt M, Szocs K, Lassegue B, Schulz E, Oelze M, Li H, Bodenschatz M, August M, Kleschyov AL et al. 2002 Effects of angiotensin II infusion on the expression and function of $\mathrm{NAD}(\mathrm{P}) \mathrm{H}$ oxidase and components of nitric oxide/cGMP signaling. Circulation Research 90 E58-E65. (doi:10.1161/01.RES.0000012569.55432.02)

Newfell BG, Iyer LK, Mohammad NN, McGraw AP, Ehsan A, Rosano G, Huang PL, Mendelsohn ME \& Jaffe IZ 2011 Aldosterone regulates vascular gene transcription via oxidative stress-dependent and independent pathways. Arteriosclerosis, Thrombosis, and Vascular Biology 31 1871-1880. (doi:10.1161/ATVBAHA.111.229070)

Oberleithner H 2005 Aldosterone makes human endothelium stiff and vulnerable. Kidney International 67 1680-1682. (doi:10.1111/j.15231755.2005.00263.x)

Ouvrard-Pascaud A, Sainte-Marie Y, Benitah JP, Perrier R, Soukaseum C, Nguyen Dinh Cat A, Royer A, Le Quang K, Charpentier F, Demolombe S et al. 2005 Conditional mineralocorticoid receptor expression in the heart leads to life-threatening arrhythmias. Circulation 111 3025-3033. (doi:10.1161/CIRCULATIONAHA.104.503706)

Owens GK 1995 Regulation of differentiation of vascular smooth muscle cells. Physiological Reviews 75 487-517.

Owens GK, Kumar MS \& Wamhoff BR 2004 Molecular regulation of vascular smooth muscle cell differentiation in development and disease. Physiological Reviews 84 767-801. (doi:10.1152/physrev.00041.2003)

Oyamada N, Sone M, Miyashita K, Park K, Taura D, Inuzuka M, Sonoyama T, Tsujimoto H, Fukunaga Y, Tamura N et al. 2008 The role of mineralocorticoid receptor expression in brain remodeling after cerebral ischemia. Endocrinology 149 3764-3777. (doi:10.1210/en.2007-1770)

Park JB \& Schiffrin EL 2001 Small artery remodeling is the most prevalent (earliest?) form of target organ damage in mild essential hypertension Journal of Hypertension 19 921-930. (doi:10.1097/00004872-20010500000013)

Pearce PT \& Funder JW 1988 Steroid binding to cardiac type I receptors: in vivo studies. Journal of Hypertension. Supplement: Official Journal of the International Society of Hypertension 6 S131-S133.

Pearce D \& Yamamoto KR 1993 Mineralocorticoid and glucocorticoid receptor activities distinguished by nonreceptor factors at a composite response element. Science 259 1161-1165. (doi:10.1126/science.8382376)

Piera-Velazquez S, Li Z \& Jimenez SA 2011 Role of endothelialmesenchymal transition (EndoMT) in the pathogenesis of fibrotic disorders. American Journal of Pathology 179 1074-1080. (doi:10.1016/ j.ajpath.2011.06.001)
Pitt B, Zannad F, Remme WJ, Cody R, Castaigne A, Perez A, Palensky J \& Wittes J 1999 The effect of spironolactone on morbidity and mortality in patients with severe heart failure. Randomized Aldactone Evaluation Study Investigators. New England Journal of Medicine 341 709-717. (doi:10.1056/NEJM199909023411001)

Pitt B, Williams G, Remme W, Martinez F, Lopez-Sendon J, Zannad F, Neaton J, Roniker B, Hurley S, Burns D et al. 2001 The EPHESUS trial: eplerenone in patients with heart failure due to systolic dysfunction complicating acute myocardial infarction. Eplerenone Post-AMI Heart Failure Efficacy and Survival Study. Cardiovascular Drugs and Therapy 15 79-87. (doi:10.1023/A:1011119003788)

Pober JS \& Sessa WC 2007 Evolving functions of endothelial cells in inflammation. Nature Reviews. Immunology 7 803-815. (doi:10.1038/ nri2171)

Pruthi D, McCurley A, Aronovitz M, Galayda C, Karumanchi SA \& Jaffe IZ 2014 Aldosterone promotes vascular remodeling by direct effects on smooth muscle cell mineralocorticoid receptors. Arteriosclerosis, Thrombosis, and Vascular Biology 34 355-364. (doi:10.1161/ATVBAHA. 113.302854)

Rickard AJ \& Young MJ 2009 Corticosteroid receptors, macrophages and cardiovascular disease. Journal of Molecular Endocrinology 42 449-459. (doi:10.1677/JME-08-0144)

Rickard AJ, Morgan J, Tesch G, Funder JW, Fuller PJ \& Young MJ 2009 Deletion of mineralocorticoid receptors from macrophages protects against deoxycorticosterone/salt-induced cardiac fibrosis and increased blood pressure. Hypertension 54 537-543. (doi:10.1161/HYPERTENSIONAHA.109.131110)

Rickard AJ, Morgan J, Bienvenu LA, Fletcher EK, Cranston GA, Shen JZ, Reichelt ME, Delbridge LM \& Young MJ 2012 Cardiomyocyte mineralocorticoid receptors are essential for deoxycorticosterone/salt-mediated inflammation and cardiac fibrosis. Hypertension $601443-1450$. (doi:10.1161/HYPERTENSIONAHA.112.203158)

Rickard AJ, Morgan J, Chrissobolis S, Miller AA, Sobey CG \& Young MJ 2014 Endothelial cell mineralocorticoid receptors regulate deoxycorticosterone/salt-mediated cardiac remodeling and vascular reactivity but not blood pressure. Hypertension 63 1033-1040. (doi:10.1161/HYPERTENSIONAHA.113.01803)

Rocha R, Rudolph AE, Frierdich GE, Nachowiak DA, Kekec BK, Blomme EA, McMahon EG \& Delyani JA 2002 Aldosterone induces a vascular inflammatory phenotype in the rat heart. American Journal of Physiology. Heart and Circulatory Physiology 283 H1802-H1810.

Rossier MF, Lenglet S, Vetterli L, Python M \& Maturana A 2008 Corticosteroids and redox potential modulate spontaneous contractions in isolated rat ventricular cardiomyocytes. Hypertension $\mathbf{5 2}$ 721-728. (doi:10.1161/HYPERTENSIONAHA.108.114223)

Rossier MF, Python M \& Maturana AD 2010 Contribution of mineralocorticoid and glucocorticoid receptors to the chronotropic and hypertrophic actions of aldosterone in neonatal rat ventricular myocytes. Endocrinology 151 2777-2787. (doi:10.1210/en. 2009-1375)

Schafer A, Fraccarollo D, Hildemann S, Christ M, Eigenthaler M, Kobsar A, Walter U \& Bauersachs J 2003 Inhibition of platelet activation in congestive heart failure by aldosterone receptor antagonism and ACE inhibition. Thrombosis and Haemostasis 89 1024-1030.

Schafer A, Vogt C, Fraccarollo D, Widder J, Flierl U, Hildemann SK, Ertl G \& Bauersachs J 2010 Eplerenone improves vascular function and reduces platelet activation in diabetic rats. Journal of Physiology and Pharmacology 61 45-52.

Schafer N, Lohmann C, Winnik S, van Tits LJ, Miranda MX, Vergopoulos A, Ruschitzka F, Nussberger J, Berger S, Luscher TF et al. 2013 Endothelial mineralocorticoid receptor activation mediates endothelial dysfunction in diet-induced obesity. European Heart Journal 34 3515-3524. (doi:10.1093/eurheartj/eht095)

Schiffrin EL 2014 Immune mechanisms in hypertension and vascular injury. Clinical Science 126 267-274. (doi:10.1042/CS20130407) 
Selye H 1946 The general adaptation syndrome and the diseases of adaptation. Journal of Clinical Endocrinology and Metabolism 6 117-230. (doi:10.1210/jcem-6-2-117)

Shen JZ, Morgan J, Tesch GH, Fuller PJ \& Young MJ 2014 CCL2-dependent macrophage recruitment is critical for mineralocorticoid receptormediated cardiac fibrosis, inflammation, and blood pressure responses in male mice. Endocrinology 155 1057-1066. (doi:10.1210/en.2013-1772)

Stankiewicz A, Gromotowicz A, Szemraj J, Wojewodzka-Zelezniakowicz M, Skrzypkowski P \& Chabielska E 2007 Acute aldosterone infusion enhances thrombosis development in normotensive rats. Thrombosis and Haemostasis 98 697-699.

Suzuki J, Iwai M, Mogi M, Oshita A, Yoshii T, Higaki J \& Horiuchi M 2006 Eplerenone with valsartan effectively reduces atherosclerotic lesion by attenuation of oxidative stress and inflammation. Arteriosclerosis, Thrombosis, and Vascular Biology 26 917-921.

Tanaka J, Fujita H, Matsuda S, Toku K, Sakanaka M \& Maeda N 1997 Glucocorticoid- and mineralocorticoid receptors in microglial cells: the two receptors mediate differential effects of corticosteroids. Glia 20 23-37. (doi:10.1002/(SICI)1098-1136(199705)20:1 < 23::AID-GLIA3 > 3.0.CO;2-6)

Usher MG, Duan SZ, Ivaschenko CY, Frieler RA, Berger S, Schutz G, Lumeng CN \& Mortensen RM 2010 Myeloid mineralocorticoid receptor controls macrophage polarization and cardiovascular hypertrophy and remodeling in mice. Journal of Clinical Investigation 120 3350-3364. (doi:10.1172/JCI41080)
Wehling M 1994 Nongenomic actions of steroid hormones. Trends in Endocrinology and Metabolism 5 347-353. (doi:10.1016/10432760(94)90165-1)

Wei Y, Whaley-Connell AT, Habibi J, Rehmer J, Rehmer N, Patel K, Hayden M, DeMarco V, Ferrario CM, Ibdah JA et al. 2009 Mineralocorticoid receptor antagonism attenuates vascular apoptosis and injury via rescuing protein kinase B activation. Hypertension 53 158-165. (doi:10.1161/HYPERTENSIONAHA.108.121954)

Wright FS \& Giebisch G 1978 Renal potassium transport: contributions of individual nephron segments and populations. American Journal of Physiology 235 F515-F527.

Wynn TA 2008 Cellular and molecular mechanisms of fibrosis. Journal of Pathology 214 199-210. (doi:10.1002/path.2277)

Yang J \& Fuller PJ 2012 Interactions of the mineralocorticoid receptor within and without. Molecular and Cellular Endocrinology 350 196-205. (doi:10.1016/j.mce.2011.07.001)

Young MJ, Moussa L, Dilley R \& Funder JW 2003 Early inflammatory responses in experimental cardiac hypertrophy and fibrosis: effects of $11 \beta$-hydroxysteroid dehydrogenase inactivation. Endocrinology 144 1121-1125. (doi:10.1210/en.2002-220926)

Zannad F, McMurray JJ, Krum H, van Veldhuisen DJ, Swedberg K, Shi H, Vincent J, Pocock SJ, Pitt B \& Group E-HS 2011 Eplerenone in patients with systolic heart failure and mild symptoms. New England Journal of Medicine 364 11-21. (doi:10.1056/ NEJMoa1009492)

Received in final form 17 October 2014

Accepted 21 October 2014

Accepted Preprint published online 21 October 2014
(C) 2015 Society for Endocrinology Printed in Great Britain 